\title{
How Polite Can you Get?: A Comparative Analysis of Interlanguage Pragmatic Knowledge in Spanish and Moroccan EFL University Students
}

\author{
Ángeles Linde \\ Facultad de Filosofia y Letras, Universidad de Granada
}

Recieved: 6 February 2008 / Accepted: 23 March 2009

ISSN: $1697-7467$

\begin{abstract}
This study is anchored in the field of interlanguage pragmatics (ITP), and the approach taken is speech-act based. In particular, our investigation compares Spanish and Moroccan university learners in the way they perceive analogies, requests and refusals with a view to shedding light on their pragmatic knowledge and strategy differences. Data were collected by a Multiple-choice discourse completion tasks questionnaire. Results show that Spanish and Moroccan speakers performed equally in terms of the apology speech act, but differed significantly when performing request and refusal speech acts. They also reveal that the two groups of participants were significantly different in terms of their indirect distractor choice, but not in their strategy and direct choices. These findings are supported by previous research.
\end{abstract}

Key words: interlanguage, speech acts, analogies, requests and refusals, strategies, distractors, negative transfer.

¿Hasta dónde llega tu educación?: análisis comparativo del conocimiento pragmático del interlenguaje en estudiantes universitarios españoles y marroquíes de ILE

RESUMEN: Este artículo se encuadra dentro del campo de la pragmática interlingüística, en particular en el estudio de los actos del habla de analogía, petición y denegación. Se plantea investigar la percepción que dos grupos de estudiantes, españoles y marroquíes, tienen de estos actos del habla con el fin de evaluar su conocimiento pragmático y detectar diferencias significativas en la elección de las opciones incorrectas. Para la recogida de datos se utilizó un cuestionario de $M C D T$. Los resultados muestran que perciben de igual forma las analogías, pero que difieren significativamente en cuanto a su percepción de las peticiones y denegaciones. Asimismo, se encontraron diferencias significativas en la elección de las opciones indirectas, pero no así en la elección de las estrategias y opciones directas. Estos resultados vienen a avalar anteriores investigaciones en este campo.

Palabras clave: interlenguaje, actos del habla, analogía, petición y denegación, transferencia negativa. 


\section{INTRODUCTION}

A look at previous interlanguage research suggests that pragmatic failure may often result in more serious communicative misunderstandings than grammatical errors, since pragmatic errors may be considered offensive by native speakers instead of simply being regarded as language errors (Thomas, 1983). The intercultural style hypothesis is supported by many funny stories that may be far from amusing, either from the perspective of the speaker, who may feel silly, helpless or rude, or from the perspective of the listener, feeling confused, insulted or angry (Kasper and Blum-Kulka, 1993; Bardovi-Harlig, 2001, Barron, 2003). Furthermore, there is evidence that grammatical competence does not imply pragmatic competence, or, in other words, grammatically advanced learners do not necessarily have concomitant pragmatic competence (Rose and Kasper, 2001; Barron, 2003). Finally, pragmatic failure may negatively affect learners' learning, preventing them from interacting with native speakers in the most desirable way (Wolfson, 1989; Boxer, 1993). In light of the above wellestablished facts, a wealth of research reflects the trend in interlanguage pragmatic studies to date.

Interlanguage has been defined as a discipline concerning «the study of non-native speakers' comprehension, production, and acquisition of linguistic action in L2" (Kasper,1998: 184), or, as Kasper herself briefly summarizes, ILP investigates how to do things with words in a second language. Learners' interlanguage turns out mainly to be the result of three overlapping influences or sources: pragmatic transfer, pragmatic overgeneralization and teachinginduced errors. Our interest here draws mainly on pragmatic transfer understood as use of L1 pragmatic knowledge to understand or carry out linguistic action in the L2. It is not pure chance that the first language and the first culture have been the most widely investigated influence on speech act realization.

Interlanguage pragmatic transfer involves pragmalinguistic and sociolinguistic transfer as well as positive and negative transfer as major inquiry focuses. Pragmalinguistic transfer refers to the process whereby the learners choose certain strategies and forms from their L1 to convey to their interlanguage. Sociolinguistic transfer is rooted in culturally different perceptions of the importance of context-internal and context-external variables (Barron, 2003: 37), or as Kasper (1992: 209) states «the influence of the social perceptions underlying language users' interpretation and performance of linguistic action in L1 on their assessment of subjectively equivalent L2 contexts.»

Regarding positive/negative transfer, research on these features has been carried out unevenly. On the one hand, positive pragmatic transfer stems from the successful extrapolation of L1 sociopragmatic anad pragmalinguistic knowledge into the target language due to similarities shared by the two languages. Rose and Kasper (2001: 6) suggest that learners may benefit from a corresponding form-function mapping between L1 and L2 if the forms used match up to L2 contexts and effects. Positive transfer can facilitate the learners' task in acquiring sociopragmatic knowledge (Mir, 1995). However, positive pragmatic transfer may raise methodological difficulties as to what extent an L2 - appropriate behaviour is due to the application of assumed universal general pragmatic knowledge rather than to positive transfer (Barron, 2003: 37). This is in line with Kasper and Schmidt, who in their seminal article (1996: 159) posed the question as to whether there is a natural route of development in the acquisition of L2 pragmatic patterns, that is to say, whether language learners develop pragmatic 
competence following some common route. Though research since then has pointed to the existence of possible development patterns in L2 pragmatic acquisition (Kasper and Rose, 2002: 140; Bardovi-Harlig, 2006: 6-20), this question can as yet not be answered conclusively. Nevertheless, to date, research indicates that speech acts may differ regarding their slower or faster development likely on account of different levels of cognitive complexity in relation to conventionalization differences in the strategies involved. Regarding refusals and requests, findings suggest that the former seem to develop more slowly than the latter (Barron, 2003; House, 1996; Trosborg, 1995; Barron and Warga, 2007).

Negative pragmative transfer results from the inappropriate projection of first languagebased sociopragmatic and pragmalinguistic knowledge onto second language context, thus leading to sociopragmatic or pragmalinguistic failure. Unlike positive transfer, a substantial body of research on the negative pragmatic transfer can be found in many aspects. Regarding pragmalinguistic negative transfer, studies have focused on pragmatic routines (House, 1996), on lexical and syntactic modification (Nikula, 1996) and on speech act realisation strategies (Trosborg, 1995). Sociopragmatic negative transfer has been studied in three main areas concerning learners' evaluation of context factors (Nikula, 1996), the overall politeness style (Takahashi and Beebe, 1993) and the relative appropriateness of a particular speech act (Robinson, 1992).

Several factors seem to influence how, why and when L1 features are transferred to an L2, some being cognitive in nature, others being regarded as non-structural. The former are categorized as a) psycholinguistic markedness, i.e., whether a learner regards a particular feature as unique to his/her L1; b) the reasonable entity principle (REP) which involves learners' beliefs as to what is possible in the L2 system; and c) psychotypology which represents learners' beliefs regarding the distance between the target language and another language, usually the L1 (Kellerman, 1983). The non-structural factors include L2 proficiency, learning context, length of residency and also social psychological factors (Barron, 2003: 39-40).

Since John Austin's speech act theory was posthumously published (1962), a large number of studies have been conducted in both cross-cultural and interlanguage pragmatics with the speech act as a unit of analysis, due to the central role that speech acts play in pragmatics competence. Although most of the research has focused on production (Cohen, 1996, suggestions in Bardovi-Harlig and Hartford, 1993, apologies in Cohen and Olstain, 1993, opting out in Rose, 1994, Rose and Ono, 1995), there are additional studies that have investigated judgment and perception (Tanaka and Kawade, 1982; Olstain and Blum-Kulka, 1985; Bergman and Kasper, 1993; Bouton, 1994; Mir, 1995; Koike, 1996). Particularly relevant for the present study, is Byon's (2004) research focused on requests performed by Korean foreign-language learners. They were required to select the most appropriate request in the given speech act situations. Some of the difficulties the participants were faced with were attributed to L1 sociopragmatic transfer, concerning the American egalitarian value system and directness in American English.

This study is anchored in the field of interlanguage pragmatics (ITP), and the approach taken is speech-act based - interest focusing on the perception of analogies, requests and refusals by EFL learners. This aims to investigate the ways NNSs' pragmalinguistic and sociopragmatic knowledge differs from that of native speakers (NSs) and among learners with different linguistic and cultural backgrounds. In particular, our investigation compares Spanish and Moroccan university learners in the way they perceive the given speech acts, with a view 
to shedding light on their pragmatic knowledge and strategy differences. The speech acts of requests, refusals and apologies were selected as they have been seen in literature as appropriate for contrasting speech-act realization across a number of languages (Hudson, 2001: 284).

The famous Cross Cultural Speech Act Realization Project (CCSARP) (Blum-Kulka, House and Kasper, 1989) was the first major attempt to study speech acts across a range of languages and cultures, carried out by a group of international researchers. They investigated whether there are universal principles in request and apology speech act realizations and what the patterns may be. Findings showed that conventionally indirect request strategies were preferred and that they could be considered a universal category of this speech act realization. Apologies, on the other hand, were found to share cross-linguistic similarities with respect to the use of an overt apology which assumes, in turn, the responsibility for the offence. Further studies have supported this finding in that apologies are performed by means of a range of strategies largely universal although influenced by a number of factors such as the learners' level of linguistic proficiency, their L1, the specific apology situation or the learners' gender, among others.

Developmental issues have been addressed in interlanguage pragmatics, particularly since the beginning of the present century, either in natural settings (for an overview see Barron, 2003; Kasper and Rose, 2002 and 2007), or in classroom intervention environments (Kasper and Rose, 2001; Alcón Soler and Martínez-Flor, 2005). Furthermore, recent research has focused on the teachability of a large range of pragmatic features and abilities (BardoviHarlig, 2001; Rose and Kasper, 2001; Martínez Fernández and Fernández Fontech, 2008), as well as strategies for learning and performing L2 speech acts (Cohen, 2005; Cubukcu, 2007; Nguyen, 2008).

Further research has been carried out with respect to two other questions especially relevant for our study: the effect of proficiency and the effect of the environment on speech act learning. Regarding proficiency levels, Enochs and Yoshitake-Strain (1999) found that TOEFL scores did not correlate with the pragmatic ability of the students. Félix- Brasdefer (2007) investigated requests by American learners of Spanish and concluded that grammatical competence follows sociopragmatic knowledge, the former being gradually developed to adjust to learners' existing pragmatic competence. Another study, focused on Spanish learners' apology performance in English (Sabaté I Dalmau and Currell I Gotor, 2007), claims that higher proficiency levels related to higher pragmalinguistic competence rather than lower levels though all of them showed L1 pragmatic influence. Nevertheless, findings indicate contradictory results with respect to the exact nature of this link (Kasper and Rose, 2002; Barron, 2003).

Recent research has given attention to the influence of learning environment on the acquisition of L2 pragmatic competence (Barron, 2003, 2007; Cohen, 2005; Schauer, 2007; among others). Barron (2003, 2007) investigates the acquisition of upgrading in refusals of offers, the subjects being Irish learners of German in an overseas context. Her findings are in line with other studies which show negative transfer and confirm the relative complexity of the speech act of refusals. In fact, regarding learners' pragmatic overgeneralization of the pragmatic routine, «learners' pragmatic competence at the end of their year abroad left them more open to pragmatic failure than prior to the year abroad» (Barron, 2003: 255). Surprisingly enough, the effect of learning environment on learners' speech act development has not yet yielded results as conclusive as were expected, banishing three myths on this issue, namely, «spending time in the target community is no panacea, length of residence is not a reliable 
predictor, and L2 classrooms can be a productive social context» (Kasper and Rose, 2002: 230). All in all, study abroad research has come to the conclusion that exposure to L2 input provokes some important developments (Barron and Warga, 2007), however, many questions remain open concerning the length of stay, the value of the learners' preparation before and after their sojourn abroad in the target speech community and many others related to individual features.

\section{Methodology}

\subsection{Aims and research questions}

This study aims to assess Spanish and Moroccan university students' English interlanguage pragmatic competence by shedding light on the following research questions:

1. To what extent do Spanish and Moroccan EFL university learners differ in their perception of apology, request and refusal speech acts?

2. Are there significant differences in their distractor choice on the pragmatic questionnaire between the Spanish and the Moroccan groups?

3. Do personal questions such as age, sex, first language, years of English study and staying in an English-speaking country correlate with interlanguage pragmatic knowledge?

\subsection{Participants}

The participants of this empirical study were 33 Spanish and 32 Moroccan university students, studying English Philology at the University of Granada and Mohamed I in Oujda ${ }^{1}$, respectively. Both groups were chosen randomly regardless of their university level, the Spanish group was attending the same optional subject assigned to the third and fourth year, while the Moroccan one varied from the first to the third university year.

\subsection{Instruments and procedures}

The interlanguage pragmatic competence was measured through a Multiple-choice discourse completion task (MDCT) questionnaire. This is a 24-item cultural questionnaire developed by Hudson, Detmer and Brown (1995: 107-114) that focuses on the speech acts of requests, refusals and apologies. We chose this questionnaire as it fitted in with our research aims and had been carefully designed, taking into account the social variables of relative power, social distance, and degree of imposition. Furthermore, five categories were adopted that include the following pragmalinguistic components: correctness of linguistic expressions and amount of information, which are more related to language correctness, whereas levels of formality, directness, and politeness represent more social aspects of language. MDCTs are flexible devices for collecting data and assessing pragmatic competence on many aspects. For instance,

1. I would like to thank Daoud Oulad Mansour for administering the questionnaire to the Moroccan students and helping me collect the ir data. 
Tanaka and Kawade (1982) investigated the notion of politeness; Bouton (1988) measured a person's ability to interpret implicatures; Rose (1994) studied non-Western contextual speech acts; Rose and Ono (1995) dealt with the methodological validation in speech act research; Roever (2005) assessed implicatures and routines, among others.

The format is a standard multiple-choice format of one answer and two distractors per item covering 24 speech acts situations, 9 being apologies, 7 requests and 8 refusals, involving pragmalinguistic and sociopragmatic knowledge. It is worth noting that, as the authors say, it was difficult or impossible to make all three of the forms parallel, due to differences inherent in the individual situations. (For further information see Hudson, Detmer and Brown, 1995: 52-54).

The students were presented with the cross-cultural pragmatics questionnaire, slightly modified by adding five questions focused on personal data. They were asked to assess each situation and choose one answer that they considered to be the most appropriate of the three possible choices. Each situation included a description of the scenario and three possible responses. Item number 8 in the MDCT, for example, reads as follows:

Situation: You are shopping for your friend's birthday and see something in a display case. You want to look at it more closely. A salesclerk comes over to you.
a. Excuse me. I want to take a look at that. Will you take it out of the case?
b. Excuse me! Show me that in the case there.
c. Excuse me. May I see that, please?

The participants' answers were rated using the answer and distractor key provided by the authors. It includes the correct answer (NS) and a set of categories, namely, strategy, short, direct, indirect, formal, polite and miscellaneous according to each situation. Strategy types involve «numerous linguistic moves that made them characteristically non-native» (Hudson, Detmer and Brown, 1995: 48). For instance, regarding apology, «offer of repair and concern for hearer strategies were those most often misused by the NNSs» (Hudson, Detmer and Brown, 1995: 54). All the analyses have been carried out using the statistical STAGRAPHICS Plus program.

\section{RESUlts}

Here we present the results related to the three research questions.

\subsection{Group differences in terms of speech act perception}

First, we explore to what extent Spanish EFL and Moroccan EFL students differ in their perception of apology, request and refusal speech acts. The descriptive statistics for the two groups' scores of native-like answers (or "correct answers») for each of the speech acts examined in this study are shown in table 1, including the number of situations where the speech act is required. 
Table 1: Descriptive Statistics for native-like answers.

\begin{tabular}{llcccccccccc}
\hline & & $\begin{array}{c}\mathrm{N}^{\circ} \\
\text { Sit. }\end{array}$ & $\begin{array}{c}\text { Total } \\
\text { core } \\
10\end{array}$ & $\begin{array}{c}\text { Min. } \\
\text { per } \\
\text { sit }\end{array}$ & $\begin{array}{c}\text { Max. } \\
\text { per sit }\end{array}$ & Mean & SD & Variance & SA & SK \\
\hline SPANISH & Apology & 9 & 5,94 & 0,3 & 1,08 & 0,66 & 0,30 & 0,09 & 0,02 & $-1,14$ \\
MOROCCAN & Apology & 9 & 5,43 & 0,4 & 0,97 & 0,60 & 0,28 & 0,07 & $-0,87$ & $-0,35$ \\
SPANISH & Request & 7 & 6,14 & 0,52 & 1,34 & 0,87 & 0,31 & 0,09 & 0,12 & $-0,68$ \\
MOROCCAN & Request & 7 & 4,02 & 0,31 & 0,89 & 0,57 & 0,22 & 0,04 & 0,53 & $-0,61$ \\
SPANISH & Refusal & 8 & 4,36 & 0,19 & 0,98 & 0,54 & 0,25 & 0,06 & 0,52 & $-0,15$ \\
MOROCCAN & Refusal & 8 & 2,66 & 0,04 & 0,59 & 0,33 & 0,18 & 0,03 & $-0,25$ & $-0,25$ \\
\hline
\end{tabular}

The results show that the total and the mean scores as well as the minimum and the maximum mark per situation achieved for each and every speech act are higher in the Spanish group than in the Moroccan one, the total mean being 0,69 for the former, and 0,45 for the latter. All this means that the Spanish speakers selected more appropriate responses than the Arab speakers for each situation, showing a more native-like performance in terms of interlanguage pragmatic competence, especially with respect to requests and refusals. Likewise, the SD-standard deviation and variance are also higher in the Spanish learners than in the Moroccan learners for the three speech acts, indicating that the former group is less homogeneous than the latter. Of particular interest are the Standard asymmetry and the Standard Kurtosis, as in this case both values are within normal limits, confirming that the data are drawn from a normal distribution.

A Levene statistic showed significance values exceeding .05 for the six columns, which indicated equal variances for all columns and thus no significant difference among the standard deviations.

\section{Variance Analysis}

The ANOVA of group difference in terms of native-like pragmatic competence is displayed in table 2. A significant difference $(\mathrm{p}<.0121)$ at the 0.05 level was found on the three speech acts, apology, request and refusal, between the Spanish speakers and the Moroccan speakers. This indicates that the two groups differ significantly in terms of their perception of the English speech acts investigated. 
Table 2: ANOVA of group difference in terms of native-like pragmatic competence.

\begin{tabular}{llcllc}
\hline & $\begin{array}{c}\text { Sum of } \\
\text { Squares }\end{array}$ & df & Mean Square & F & Sig. \\
\hline Between groups & 1,17013 & 5 & 0,234027 & 3,36 & $\mathbf{0 , 0 1 2 1}$ \\
Within groups & 2,92266 & 42 & 0,0695872 & & \\
Total & 4,0928 & 47 & & & \\
\hline
\end{tabular}

To further show the significance of these differences, a multiple range test was conducted to determine the means being significantly different from one other. The results showed statistically significant differences between the following pairs:

* Spanish apology native-like answers and Moroccan refusal native-like answers.

* Spanish apology native-like answers and Spanish request native-like answers.

* Moroccan apology native-like answers and Moroccan refusal native-like answers.

* Spanish request native-like answers and Moroccan request native-like answers.

* Spanish request native-like answers and Spanish refusal native-like answers.

* Spanish request native-like answers and Moroccan refusal native-like answers.

The above pairs reveal that there were significant differences between Spanish apologies and Moroccan refusals, Spanish requests and Moroccan requests and refusals. Likewise, Spanish differ significantly in their apology and request choice as well as between request and refusal speech acts. On the other hand, Moroccan speakers perform significantly differently when performing apologies and refusals.

\section{Law Hypothesis Contrast}

Investigation was carried out to test the hypothesis that the choice of the correct options is equally distributed among the three speech acts for the two groups of participants; in other words, if the two groups of participants perform similarly with respect to the three speech acts independently. Law Hypothesis Contrast assumes that the variances are similar and thus if $\mathrm{p}$ $>.05$, the null hypothesis is accepted; while if $\mathrm{p}<.05$, the null hypothesis is rejected.

Table 3: Results of hypothesis contrast for native-like answer means.

\begin{tabular}{llll}
\hline & T-statistics & p-value & Null hypothesis \\
\hline $\begin{array}{l}\text { Spanish/Moroccan } \\
\text { Apologies }\end{array}$ & 0,091 & $\mathbf{0 , 9 2 7}$ & 0,05 \\
$\begin{array}{l}\text { Spanish/Moroccan } \\
\begin{array}{l}\text { Requests } \\
\text { Spanish/Moroccan }\end{array}\end{array}$ & 3,760 & $\mathbf{0 , 0 0 0}$ & 0,05 \\
Refusals & 2,969 & $\mathbf{0 , 0 0 4}$ & 0,05 \\
\hline
\end{tabular}


Table 3 displays the results of hypothesis contrast analysis carried out to find out differences between the means for native-like answers regarding the three speech acts independently, assuming similar variances. Since the p-value for apologies $(p>.091)$ is higher than 0,05 , the null hypothesis is accepted, suggesting that the choice that the Spanish and Moroccan speakers made is similar and therefore they perform equally in terms of cross-cultural pragmatic competence for apologies. Nevertheless, the $\mathrm{p}$ - values for requests $(\mathrm{p}<.000)$ and refusals $(\mathrm{p}<$ .004 ) being lower than 0,05 indicate that the null hypothesis is rejected, therefore suggesting that the choices of these speech acts are significantly different between Spanish and Moroccan speakers. This, in turn, means that both groups differ significantly when performing requests and refusals.

\subsection{Group differences in terms of distractor choice}

Several ANOVAs were conducted to explore the differences between the distractors chosen for each speech act. Table 4 shows the three more widely used distractors and therefore provides us with more interesting insights. A significant difference was found on the strategy $(\mathrm{p}<.0241)$ and direct distractors $(\mathrm{p}<.0022)$ at 0.05 level, but not on the indirect one $(\mathrm{p}$ $>.1814$ ). This indicates that the two groups performed similarly in terms of their distractor choice with respect to strategy and direct distractors, but not with respect to their indirect choice.

Table 4: ANOVA of group difference in terms of optional distractors.

\begin{tabular}{lllllll}
\hline & & $\begin{array}{l}\text { Sum of } \\
\text { Squares }\end{array}$ & df & $\begin{array}{l}\text { Mean } \\
\text { Square }\end{array}$ & F & Sig. \\
\hline STRATEGY & Between groups & 1,0909 & 5 & 0,2181 & 2,91 & $\mathbf{0 , 0 2 4 1}$ \\
& Within groups & 3,1489 & 42 & 0,0749 & & \\
\multirow{2}{*}{ DIRECT } & Total & 4,2398 & 47 & & & \\
& Between groups & 0,3756 & 5 & 0,0751 & 4,32 & $\mathbf{0 , 0 0 2 2}$ \\
& Within groups & 0,7300 & 42 & 0,0173 & & \\
INDIRECT & Total & 1,1056 & 47 & & & \\
& Between groups & 0,5792 & 3 & 0,1930 & 3,22 & 0,1814 \\
& Within groups & 0,1800 & 3 & 0,0600 & & \\
& Total & 0,7593 & 6 & & & \\
\hline
\end{tabular}

\subsection{Personal features and interlanguage pragmatic knowledge}

The third research question focused on correlations between personal questions such as age, sex, first language, years of English study and staying in an English-speaking country and interlanguage pragmatic knowledge.

Several Regression analyses were carried out to determine correlations between personal variables and the total marks obtained for each group. No statistically significant correlations were found between Age, Sex and the total marks for any of the two groups, Spanish and Moroccan. Surprisingly, neither was there a statistically significant correlation between study abroad and global marks for the Spanish group. 
Nevertheless, findings indicate that there exists a statistically significant, though relatively weak, relationship between the years of English study and the total marks for a $90 \%$ confidence interval, $(\mathrm{p}<.074)$ for the Spanish group. Likewise, a statistically significant relationship between total scoring and native language (Arab or Berber) was found for the Moroccan group for a $90 \%$ confidence interval, $(\mathrm{p}<.082)$, this being also relatively weak.

Finally, results of the native-like answers were analyzed through regression analyses, showing no significant correlations between any of the three speech acts, apologies, requests and refusals, for any of the two groups.

\section{Discussion}

The results of this study on English interlanguage pragmatic knowledge of Spanish and Moroccan university learners have provided us with interesting findings either confirming or rejecting our research questions. First, concerning the Spanish test takers' overall perception of the given speech acts, results assign to them a moderately high level $(0,69)$, supporting, on the other hand, the claim made in the current ILP research that L2 pragmatic knowledge is incomplete for many learners, even for advanced ones (Nguyen, 2008). By comparing the Spanish and the Moroccans' performance on apologies, requests and refusals, we have found that there are significant differences between these groups, which mean that the Spanish group perceives the speech acts in a more native-like manner. Nevertheless, both groups show agreement on the speech act of refusal as being the most difficult, since this obtained the lowest mean. Moreover, we observed that there were statistically significant differences at three levels: a) within the Spanish group, their performance differed significantly between requests and the other two speech acts (apologies and refusals); b) within the Moroccan group, they performed significantly differently when dealing with apologies and refusals; c) regarding the two groups, there were significant differences between Spanish apologies and Moroccan refusals, Spanish requests and Moroccan requests and refusals. However, it is noteworthy that no significant difference was found with respect to apologies between the two groups, which indicates a similar interlanguage pragmatic ability on the matter. Further analyses through the Hypothesis Contrast confirmed this finding, revealing that Spanish and Moroccan speakers performed equally in terms of the apology speech act, but differed significantly when performing request and refusal speech acts.

The above results can possibly be explained in several ways, but first and foremost we consider that the outstanding reason may be attributed to their first language influence or negative L1 transfer. Though it is not surprising that both groups convey their L1 pragmatic principles to their interlanguage pragmatic performance, Spanish language is much more closely related to English language in a number of features, both being European languages and thus sharing many conventional behaviours or sociopragmatic background. This, in turn, likely relates to the psychotypology factor (Kellerman, 1983) involved in pragmatic developments which entails learners' beliefs with respect to the distance between L1 and the target language. In this regard, it should be stressed that the Moroccan group is known to be made up of multilingual and multicultural speakers. It is worth noting that L1 language influence was also observed in our study regarding Moroccan speakers' two different first languages: Moroccan 
Arabic and Berber, revealing a weak though statistically significant correlation between total scoring and first languages.

These findings are also in line with previous research already discussed in the introduction. First, apologies seem to share cross-linguistic similarities with respect to the use of an overt apology, being performed by means of a range of strategies largely universal, although influenced by a number of factors (Blum-Kulka, House and Kasper, 1989). This supports, therefore, Spanish and Moroccans' similar perception of the apology speech act found in our analysis. Secondly, the difficulty in the perception of the refusal speech act encountered by Spanish and Moroccan speakers has also been confirmed by a number of authors. Hudson (2001) for instance reports in his study to assess pragmatic competence of Japanese of learners of English as a second language that refusals seemed to be more difficult to perform than apologies and requests, involving a more complex face-saving move. Similarly, in studies focused on patterns of speech act development, refusals appear to be among the speech acts which are slowest to develop, while requests are seen as among the fastest in learners' interlanguage (Barron, 2003; House, 1996; Trosborg, 1995; Barron and Warga, 2007).

Research question two posed differences between the Spanish and the Moroccan groups in the distractor choice on the pragmatic test. Three distractors out of six, polite, formal and miscellanies, were discarded due to their low occurrence in the choices, while the other three, strategy, direct and indirect distractors, were analysed. The results showed that the two groups of participants were significantly different in terms of their indirect distractor choice, but not in their strategy and direct choices. This finding again corresponds well to L1 negative transfer. It is well-known that Spanish speakers are considered to have more direct ways of addressing than other European peoples, while Moroccan people are regarded as more indirect in terms of social behaviour. This supports Byon's (2004) claim in that a main source of difficulty for the Korean foreign-language learners in performing requests was due to the American egalitarian value system and directness in American English.

Generally, indirectness can be considered a feature of L2 learners' pragmatic competence. For instance, in terms of criticism realization, the learners tend to be less direct and to vary more in their choice of criticism strategies than native speakers (Nguyen, 2008). In this line, Yamashita (1996) reported that conventionally indirect request strategies were preferred by the learners and therefore they could be considered a universal category of this speech act realization. It should also be noted that the correct answers and the distractors in our questionnaire mainly differ in three aspects: strategy use, sociopragmatic misjudgments, and phrasing (pragmalinguistics), and that some Spanish and Moroccan responses, although differing from the native responses, particularly in pragmatic terms, may not be considered entirely incorrect.

Research question three covered quite a number of personal variables aiming to elicit their influence on the learners' pragmatic test. This was partially rejected since some personal questions (sex, gender and study abroad) taken into account in this study do not significantly correlate with the total marks obtained in the correct answers, except for two cases: Moroccans' two first languages, as already commented, and Spanish students' years of study. Findings reveal a significant positive correlation between the number of years of English study and the total scoring in the Spanish group though it depicts a relatively weak relationship between the two variables. In spite of the common belief that language proficiency enhances pragmatic, studies have not yet reached an agreement, showing contradictory results with respect to the extent to which proficiency relates to pragmatic competence (Kasper and Rose, 
2002; Barron, 2003; Félix- Brasdefer, 2007; Sabaté I Dalmau and Currell I Gotor, 2007). Finally, as regards the effect on pragmatic knowledge of a sojourn abroad, curiously enough, the results of the correlation analysis indicated that the Spanish test takers' interlanguage pragmatic knowledge did not seem to increase with their staying in an English-speaking foreign country. A plausible reason could lie in the fact that the Spanish group was quite homogeneous with respect to their overseas experience, most of them had been abroad as Erasmus students for a course, therefore not differing substantially in the matter. On the other hand, Spanish' overseas experience could have contributed to their better performance in comparison with the Morrocan learners, although this variable was not analyzed in this study. Nevertheless, general findings highlight an increasingly L2-like pragmatic competence in learners' interlanguage, although unevenly developed. Access to native speakers alone is not enough, rather they must encounter appropriate opportunities to receive input and practise real communication exchanges.

\section{Concluding Remarks}

In the light of the discussion above and assuming the limitations of this study, relevant correspondence with above quoted studies has been found, though they do not share their linguistic background with our subjects. These findings raise implications for policy and institutional changes concerning the role of pragmatic competence in learners' overall communicative competence. Syllabuses need to take into account explicit teaching of pragmatic aspects not only at university but at secondary levels to help learners be aware of their learning and use of L2 pragmatics. It would also imply going a few steps further than the classroom, encouraging contacts with native speakers and the target culture through films, videos, music, excursions or study abroad sojourns, in agreement with increasing pedagogical reflections that point in this direction (Uribe, Gutiérrez and Madrid, 2008). Last but not least, teachers are required to be the first to break away from old pedagogical routines, offering learners authentic input that will enable them to make informed choices while acknowledging their individuality and respecting their system of values and beliefs (Thomas, 1983).

\section{REFERENCES}

Austin, J.L. (1962). How to do things with words. Oxford: Calderon Press.

Alcón Soler, E. and Martínez-Flor (eds). (2005). Pragmatics in instructed language learning. [Special issue]. System, 33 (3).

Bardovi-Harlig, K. (2001). «Evaluating the empirical evidence: grounds for instruction in pragmatics?», in Rose, K.R. and Kasper, G. (eds.), Pragmatics in Language Teaching (pp. 13-32). New York: Cambridge University Press.

Bardovi-Harlig, K. (2006). «On the role of formulas in the acquisition of L2 pragmatics». Pragmatics and Language Learning, Bardovi-Harlig, K, Félix-Brasdefer, C. J. and Alwiya, O. (eds.), 11: $1-28$.

Bardovi-Harlig, K. and Hartford, B (1993). «Learning the rules of pragmatic talk: A longitudinal study of pragmatic change». Studies in Second Language Acquisition, 15: (3): 279-301. 
Barron, A. (2003). Acquisition in interlanguage pragmatics: learning how to do things with words in a sudy abroad context. Amsterdam/Philadelphia: John Benjamins.

Barron, A. (2007). «Ah no honestly we're okay:» Learning to upgrade in a study abroad context». Intercultural Pragmatics, 4-2:129-166.

Barron, A. and M. Warga (2007). «Acquisitional pragmatics: focus on foreign language learners». Intercultural Pragmatics, 4-2: 113-127.

Bergman, M. and Kasper, G. (1993). «Perception and performance in native and nonnative apology», in G. Kasper and S. Blum-Kulka (eds.) Interlanguage Pragmatics, (pp. 82107). Oxford: Oxford University Press.

Blum-Kulka, S. House, J. and Kasper, G. (eds.) (1989), Cross-cultural pragmatics: requests and apologies[Advances in Discourse Processes 3] Norwood, NJ: Ablex.

Bouton, L.F. (1988). "A cross-cultural study of ability to interpret implicatures in English». World Englishes, 7 (2): 183-196.

Bouton, L.F. (1994) «Conversational implicature in a second language: learned slowl when not deliberatel taught». Journal of Pragmatics, 22 (2): 157-167.

Boxer, D. (1993). «Complaints as positive strategies: what the learner needs to know». TESOL Quarterly, 27 (29: 227-299.

Byon, A.S. (2004). «Learning linguistic politness». Applied Language Learning, 14: 37-62.

Cohen, A.D. (1996). «Investigating the production of speech act sets, in S.M. Gass and J. Neu (eds.), Speech acts across cultures: Challenges to communication in second language (pp. 21-3). Berlin: Mouton de Gruyter.

Cohen, A.D. (2005) «Strategies for learning and performing L2 speech acts. Intercultural Pragmatics, 2-3: 275-301.

Cohen, A.D. and Olshtain, E. (1993). «The production of speech acts by EFL learners». TESOL Quarterly 27 (1): 33-56.

Cubukcu, F. (2007). «Crosscultural differences in learning strategies and study-skills». Porta Linguarum, 8: 99-116.

Enochs, K and S.Yoshitake-Strain (1999). «Evaluating six measures of EFL learners' pragmati competence». JALT Journal, 21 (1): 29-50.

Félix-Brasdefer, J.C. (2007). «Pragmatic development in the Spanish as a FL classroom». Intercultural Pragmatics, 4(2): 159-185.

House, J. (1996). «Developing pragmatic fluency in English as a foreign language: Routines and metapragmatic awareness». Studies in Second Language Acquisition, 18 (2): 225-252.

Hudson, J. (2001). «Indicators for pragmatic instruction: some quantitative tools», in Rose, K.R. and Kasper, G. (eds.), Pragmatics in Language Teaching. New York: Cambridge University Press.

Hudson, T, Detmer, E. and Brown, J.D. 1995. Developing Prototypic Measures of Cross- Cultural Pragmatics. Honolulu, Hawaii. University of Hawaii Press.

Kasper, G. (1992). «Pragmatic transfer». Second Language Research, 8: 203-231.

Kasper, G. (1998). «Interlanguage Pragmatics», in H. Byrnes, (ed.). Learning Foreign and Second Languages: Perspectives in Research and Scholarship. New York: The Modern Language Association of America, 183-208.

Kasper, G and Blum-Kulka, S. (1993). Interlanguage Pragmatics. Oxford: Oxford University Press.

Kasper, G and Rose, K.R. (2001). Pragmatics in Language Teaching.Cambridge: Cambridge University Press. 
Kasper, G and. Rose, K.R (2002). Pragmatic development in a second language. Michigan: Blackwell.

Kasper, G. and Schmidt, R. (1996). «Developmental issues in interlanguage pragmatics». Studies in Second Language Acquisition, 18 (2): 149-169.

Kellerman, E. (1983). «Now you seeit, now you don’t «. In S. Gass, and L. Selinker (eds.), Language transfer in language learning (pp. 112- 134). Rowley, MA: Newbury House.

Koike, D. (1996). "Transfer of pragmatic competence and suggestions in Spanish foreign language learning», in S. Gass, and J. Neu (eds.), Speech acts across cultures (pp.257-281). Berlin: Mouton de Gruyter.

Martínez Fernández, B. and Fernández Fontech, A. (2008). «The teachability of pragmatics in SLA: friends' humour throuh Grice». Porta Linguarum, 10: 31-56.

Mir, M. (1995).» «The perception of social context in request performance», in L. Bouton (ed.), Pragmatics and language learning, monograph series, 6: 105-120. University of Illinois, Urbana- Champaign

Nguyen, T.T.M. (2008) «Critizing in an L2: Pragmatic strategies used by Vietnamese EFL learners» Intercultural pragmatics 5-1: 41-66.

Nikula, T. (1996). Pragmatic force modifiers: a study in interlanguage pragmatics. Jväskylä: Jväskylän Yliopisto.

Olshtain, E. and Blum-Kulka, S. (1985). « Degree of approximation: Nonative reactions to native speech act behaviour», in S. Gass and C. Madden (eds.), Input in second language acquisition (pp. 303-325). New York: Newbury House.

Robinson, M.A. (1992). «Introspective methodology in interlanguage pragmatics research», in G. Kasper (ed.), Pragmatics of Japanese as native and target language.Honolulu, HI: Second Language Teaching and Curriculum Center, University of Hawaii. Technical Report \#3.2782.

Roever, C. (2005). Testing ESL Pragmatics: Development and validation of a Web-based assessment battery. Frankfurt am Main: Peter Lang.

Rose, K.R. (1994). «On the validity of discourse completion tests in non-western contexts». Applied Lingustics, 15 (1), 1-14).

Rose, K.R. (2001). «Compliments and compliment responses in film: implications for pragmatics reseach and language research». International Review of Applied Linguistics in Language teaching (IRAL). 39:309-326.

Rose, K.R. and Kasper, G. (2001), Pragmatics in Language Teaching. New York: Cambridge University Press.

Rose, K.R. and Ono, R. (1995). «Eliciting speech act data in Japanese: the effect of questionnaire type». Language Learning, 45 (2): 191-223.

Sabaté i Dalmau, M and Curell i Gotor, H. (2007). «From «Sorry very much» to «I'm ever so sorry»: Acquisitional patterns in L2 apologies by Catalan learners of English»

Intercultural Pragmatics, 4-2:287- 316.

Schaue, G.A. (2007). «Findings the right words in the study abroad context: The development of German learners' use of external modifiers in English». Intercultural Pragmatics, 4-2: 193-220.

Takahashi, T. (1996). «Pragmatic transferability». Studies in Second Language Acquisition, 18 (2): $189-223$.

Takahashi, T. and Beebe, L. M. (1993).»Cross-linguistic influence in the speech act of correction», in G. Kasper and S. Blum-Kulka (eds.), Interlanguage Pragmatics (pp. 138-158). Oxford: Oxford University Press. 
Tanaka, K. and Kawade, S. (1982). «Politeness strategies and second language acquisition». Studies in Second Language Acquisition, 5(1), 18-33.

Thomas, J. (1983). «Cross- cultural pragmatic failure». Applied Linguistics, 4 (2): 91-112.

Trosborg, A. (1995). Interlanguage pragmatics: requests, complaints, apologies [Studies in Anthropological Linguistics 7]. Berlin: Mouton de Gruyter.

Uribe, D, Gutiérrez, J. and Madrid, D. (2008). «Las actitudes del alumnado hacia el aprendizaje del inglés como idioma extranjero: estudio de una muestra en el sur de España». Porta Linguarum, 10: 85-100.

Warga, M. (2007). «Interlanguage pragmatics in L2 French», in French Applied Linguistics, D. Ayoun (ed.), (pp. 171-207). Amsterdam/Philadelphia: Benjamins.

Wolfson, N., Marmor, T. and Jones, S. (1989). «Problems in the comparison of speech acts across cultures», in S. Blum-Kulka, J. House and G. Kasper (eds.), Cross-cultural pragmatics: requests and apologies (pp. 174-196). Norwood, New Jersey: Ablex Publishing Corporation.

Yamashita, S. O.(1996). Six measures of JSL pragmatics. Honolulu: Second Language Teaching and Curriculum Centre of University of Hawaii at Manoa. 